\title{
Терміни виникнення ранніх і пізніх форм інфекційного ендокардиту протезованого клапана серця
}

\author{
Крикунов О. А., Колтунова Г. Б., Списаренко С. П., Малишева Т. А.
}

\author{
ДУ «Національний інститут серцево-судинної хірургії імені М. М. Амосова НАМН» (Київ)
}

\begin{abstract}
Інфекційний ендокардит протезованого клапана серця (IE ПКС) є одним із важких ускладнень післяопераційного періоду з боку імплантованих штучних клапанів серця. Особливою важкістю відрізняються ранні форми IE ПКС, летальність при яких досягає 75\%. Мета - дослідити терміни виникнення ранніх і пізніх форм IE ПКС. Матеріали та методи. Основу дослідження склали клінічні дані 276 хворих на IE ПКС, які пройшли обстеження та лікування в ДУ «Національний інститут серцево-судинної хірургії іме-

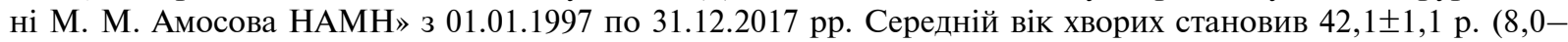
73,0 р.). Результати. Залежно від виникнення перших симптомів IЕ група хворих із ПКС була підрозділена на ранні (менше 2 місяців після операції) та пізні (більше 2 місяців після операції) форми захворювання, які включали 109 (39,5\%) і 167 (60,5\%) випадків відповідно. До кінця другого місяця ризик виникнення IE ПКС становить 7\%, а до кінця першого року після операції він зменшується майже вдвічі - 4\%. Висновки. Розподіл випадків виникнення IE ПКС у післяопераційному періоді має нерівномірній характер. Найбільша кількість випадків припадає на четвертий тиждень після імплантації штучного клапана серця.
\end{abstract}

Ключові слова: інфекційний ендокардит протезованого клапана серия, ранні форми, пізні форми.

Інфекційний ендокардит протезованого клапана серця (IE ПКС) є одним з важких ускладнень післяопераційного періоду з боку імплантованих штучних клапанів серця, незалежно від матеріалів, використаних для їх виготовлення, і механізмів функціонування. Принциповою відмінністю IЕ ПКС від інших варіантів клапанної патології ревматичного або дегенеративного генезу є поєднання бактеріємії, системної запальної відповіді та швидкої інфекційної деструкції клапанного апарату. Прогресування органної недостатності, як результат септичного стану, значно ускладнює проведення повторних хірургічних втручань.

IE ПКС потребує складних хірургічних втручань [2, 3], а іноді призводить до летальних клінічних наслідків, особливо у пацієнтів із раннім IЕ ПКС [4-8]. Частота виникнення IE ПКС становить приблизно 0,5\% на рік на пацієнта. У 1996 р. Lytle та співавт. [4] показали, що $13 \%$ із 146 хворих на IE ПКС мали смертельні випадки в лікарнях, а в 2014 році Grubitzsch та співавт. [5] показали, що госпітальна летальність склала 12,8\% серед 149 послідовних пацієнтів з IE ПКС. Хірургічний ризик репротезування штучного клапана серця при IE ПКС залишається високим [1].

IE ПКС становить 10-30\% усіх випадків IE [9] i уражає як механічні, так і біологічні моделі штучних клапанів серця. ПКС був зареєстрований у $16 \%$ інфекційного ендокардиту в дослідженні у Франції, у $26 \%$ випадках у Euro Heart Survey54 та в 20\% випадків серед 2670 хворих з установленим IE ICE Prospective Cohort Study [7, 8]. ПКС асоційований із труднощами діагностики, визначенням оптимальної терапевтичної стратегії та несприятливим прогнозом.

Існують різні точки зору щодо термінів виявлення раннього та пізнього IE ПКС. Згідно з ESC Guidelines for the management of infective endocarditis 2015, ранній IE ПКС визначається як IE, що розвивається протягом року після хірургічного втручання, а пізній IE ПКС як такий, що розвивається через один рік після операції (на підставі відмінностей у спектрі мікробіологічних збудників до та після цього відрізку часу). Важливим залишається питання етіології збудника IE ПКС. За результатами останнього проспективного мультицентрового міжнародного регістру було виявлено $37 \%$ випадків IE ПКС, асоційованого з нозокоміальною інфекцією [8].

Жодний із сучасних посібників, присвячених проблемам діагностики та лікування сепсису, не розглядає інфекційний ендокардит, який має в наявності всі патогенетичні компоненти сепсису - вогнище інфекційного ураження тканин організму, бактеріємію, синдром системної запальної відповіді. Причиною цього $\epsilon$ неможливість класифікувати IE в сучасній діагностичній системі сепсису і особливо в системах стратифікації тяжкості стану хворих на сепсис. Це неможливо, оскільки при IE існують унікальні причини порушення системної та внутрішньосерцевої гемодинаміки руйнування клапанного апарату, а органна дисфункція виникає внаслідок спільного впливу мікро-макроемболіі, мікробної інтоксикації та факторів запалення. Особливою важкістю відрізняються ранні форми IE 
ПКС, летальність при яких досягає 75\% [7]. Гостра маніфестація захворювання зустрічається у $30 \%$ хворих i, як правило, проявляється гострою дисфункцією протеза з розвитком гострої серцевої недостатності [8].

Мета - дослідити терміни виникнення ранніх і пізніх форм IЕ ПКС.

Матеріали та методи. Основу дослідження склали клінічні дані 276 хворих на IE ПКС, які пройшли обстеження та лікування в ДУ «Національний інститут серцево-судинної хірургії імені М. М. Амосова НАМН» з 01.01.1997 по 31.12.2017 р. Середній вік хворих становив $42,1 \pm 1,1$ р. $(8,0-73,0$ р.).

Основні клінічні критерії діагностики IE - бактеріологічні та ехокардіографічні. У 81 (29,3\%) випадку вдалося ідентифікувати типові для IЕ мікроорганізми (стрептококи, ентерококи та стафілококи) із трьох окремих проб крові, взятих з інтервалом у 12 годин.

При проведенні черезстравохідного та трансторакального ЕхоКГ-дослідження було виявлено ознаки IE ПКС у $226(81,9 \%)$ випадках. Найбільш частими ознаками були вегетації - у 174 (63,0\%) випадках. Внутрішньосерцеві абсцеси та утворення патологічних сполучень між порожнинами серця виявлені в 136 (49,3\%) i $17(6,2 \%)$ випадках відповідно. Найбільш частими проявами дисфункції ПКС стали ізольована регургітація або іії комбінація з ознаками обструкції ПКС - 66 $(23,9 \%)$ і $142(51,4 \%)$ випадки відповідно. Разом із тим у $50(18,1 \%)$ хворих ЕхоКГ-ознаки IЕ були мало переконливі.

Саме в цій групі хворих найбільше значення у встановленні діагнозу мали другорядні критерії IE ПКС. Другорядний клінічний критерій у досліджуваній групі хворих був представлений таким чином: вихідна внутрішньосерцева патологія, наявність штучного клапана серця (ШКС) - 276 (100,0\%); анамнез ін'єкційного використання наркотичних препаратів - $10(3,6 \%)$ випадків.

Результати та обговорення. При середньому віці по групі 42,1+1,1 року найбільша кількість пацієнтів знаходилася на 5-6-му десятилітті життя - 145 (52,5\%) випадків. При цьому група хворих $(n=7)$ з імплантацією ШКС у тристулкову позицію має достовірно менше значення середнього віку $-24,7 \pm 4,6(\mathrm{p}<0,01)$.

Аналіз вихідного етіологічного спектра набутих вад серця показав, що ревматичний генез захворювань переважав і реєструвався в $157(56,9 \%)$ випадках. Спостерігалось достовірне $(\mathrm{p}<0,01)$ переважання ревматичного генезу при IЕ ПМК порівняно з IE ПКС правих відділів серця. Другою важливою причиною виявився вихідний IE нативних клапанів серця - $93(33,7 \%)$ випадки. При цьому є достовірне $(\mathrm{p}<0,01)$ переважання IE у групі хворих з ураженням клапанів правих відділів серця - $6(85,7 \%)$ випадків. Початкове інфекційне ураження аортального та поєднання уражень мітрального та аортального клапанів представлено 53 (19,2\%) і 13 (4,7\%) випадками відповідно. Вади дегенеративного

\section{Таблиця 1}

Вихідна етіологія вад природних клапанів серия при різних анатомічних позиціях імплантованих ШКС

\begin{tabular}{lcccccccc} 
& \multicolumn{8}{c}{ Позиція ШКС } \\
\cline { 2 - 10 } $\begin{array}{l}\text { Вихідна } \\
\text { етіологія }\end{array}$ & \multicolumn{2}{c}{ АВ } & \multicolumn{7}{c}{ МВ } & $\mathbf{n}$ & $\%$ & $\mathbf{n}$ & $\%$ & $\mathbf{n}$ & $\%$ \\
\hline Ревматизм & 67 & 51,9 & 73 & $67,6^{* *}$ & 17 & 53,1 & 0 & - \\
\hline $\begin{array}{l}\text { Дегенера- } \\
\text { тивна вада }\end{array}$ & 6 & 4,7 & 10 & 9,3 & 2 & 6,3 & 0 & - \\
\hline $\begin{array}{l}\text { Вроджена } \\
\text { вада }\end{array}$ & 3 & 2,3 & 4 & 3,7 & 0 & - & 1 & 14,3 \\
\hline $\begin{array}{l}\text { Інфекційний } \\
\text { ендокардит }\end{array}$ & 53 & 41,1 & 21 & $19,4^{* *}$ & 13 & 40,6 & 6 & $85,7^{* *}$ \\
\hline Разом & 129 & 100,0 & 108 & 100,0 & 32 & 100,0 & 7 & 100,0
\end{tabular}

AВ - аортальна вада, МВ - мітральна вада, МАВ - мітральноаортальна вада, ТВ - трикуспідальна вада

Примітка. Рівні значущості залежно від анатомічних позицій імплантованих ШКС: ** $(\mathrm{p}<0,05)$

генезу та вроджені аномалії клапанних структур реєструвалися у $18(6,5 \%)$ і $8(2,9 \%)$ випадках відповідно (табл. 1).

Серед причин розвитку бактеріємії як основного патогенетичного компонента виникнення IE ПКС переважали нозокоміальні фактори (інвазивні діагностичні та лікувальні маніпуляції) - 118 (42,8\%) спостережень. Групу нозокоміальних випадків IЕ ПКС утворюють усі випадки раннього IЕ ПКС лівих відділів серця - 107 $(38,8 \%)$ випадків, а також $11(4,0 \%)$ випадків пізнього IE ПКС (з 167 зареєстрованих пізніх форм IE ПКС). Другою за значущістю виявилася група факторів, пов'язаних із переохолодженням і бронхолегеневими захворюваннями, яка включала $78(28,3 \%)$ випадків; парентеральне використання наркотичних засобів було зареєстровано у $10(3,6 \%)$ хворих в анамнезі. Разом із тим у $70(25,4 \%)$ хворих можливих причин бактеріємії виявити не вдалося. Особливістю групи хворих з інфікуванням ШКС, імплантованих у тристулкову позицію, є домінування серед причин виникнення IE ПКС наркоманії - $6(85,7 \%)$ випадків (табл. 2).

Розподіл 276 хворих з ІЕ ПКС відповідно до терміну появи перших симптомів інфекційного процесу свідчить, що найбільша кількість хворих припадає на перший рік після операції - 193 (69,9\%) випадки. При цьому ми виявили, що в перший післяопераційний рік частота реєстрації випадків IE ПКС зменшується з плином часу з моменту хірургічного втручання. Так, на перший і другий місяць після операції припадає 67 $(34,7 \%)$ і $42(21,8 \%)$ випадки захворювань відповідно. Більш детальний аналіз розподілу хворих у перші два місяці після операції показав, що найбільша кількість випадків IE ПКС припадає на четвертий тиждень після операції - 25 (22,9\%) випадків (табл. 3). 


\section{Таблиця 2}

Причини виникнення IЕ ПКС при різних анатомічних позиціях імплантованих ШКС

\begin{tabular}{|c|c|c|c|c|c|c|c|c|}
\hline \multirow[b]{3}{*}{ Причини IE } & \multicolumn{8}{|c|}{ Позиція ШКС } \\
\hline & \multicolumn{2}{|c|}{$A B$} & \multicolumn{2}{|c|}{ MB } & \multicolumn{2}{|c|}{ MAB } & \multicolumn{2}{|r|}{ TB } \\
\hline & $\mathbf{n}$ & $\%$ & $\mathbf{n}$ & $\%$ & $\mathbf{n}$ & $\%$ & $\mathbf{n}$ & $\%$ \\
\hline $\begin{array}{l}\text { Бронхо- } \\
\text { легеневі }\end{array}$ & 37 & 28,7 & 32 & 29,6 & 8 & 25,0 & 1 & 14,3 \\
\hline $\begin{array}{l}\text { Нозоко- } \\
\text { міальні }\end{array}$ & 59 & 45,7 & 45 & 41,7 & 14 & 43,8 & 0 & - \\
\hline Наркоманія & 2 & 1,6 & 2 & 1,9 & 0 & - & 6 & $85,7^{* * *}$ \\
\hline $\begin{array}{l}\text { Не встанов- } \\
\text { лено }\end{array}$ & 31 & 24,0 & 29 & 26,9 & 10 & 31,3 & 0 & - \\
\hline Разом & 129 & 100,0 & 108 & 100,0 & 32 & 100,0 & 7 & 100,0 \\
\hline
\end{tabular}

АВ - аортальна вада, МВ - мітральна вада, МАВ - мітральноаортальна вада, ТВ - трикуспідальна вада

Примітка. Рівень значущості при порівнянні груп хворих залежно від наявності наркоманії в анамнезі: *** $(\mathrm{p}<0,001)$

Таким чином, в перші два місяці після операції виникає 109 (39,5\%) випадків IЕ ПКС, які класифіковані нами як ранні форми.

Для описання динаміки зміни кількості хворих пацієнтів була розроблена математична модель такого вигляду:

$y=a t^{b} e^{-c t}+d$,

де $y$ - кількість хворих;

$t-$ час виникнення захворювання (тижні);

$a, b, c, d$ - параметри моделі: $a$ - параметри масштабу, $b$ - характеристика нелінійності процесу, $c$ - швидкість зниження ризику захворювання, $d-$ прогнозована величина захворюваності після закінчення аналізованого періоду.

Динаміку розподілу хворих на IE ПКС в перші 2 місяці після операції відображає функція (рис. 1).

За допомогою пакета Statistica 8.0 методом Лівенверга-Маркгуарда були розраховані всі параметри моделі (табл. 4). Найбільший інтерес становить величина d, а точніше, верхня межа ії довірчого інтервалу $\mathrm{d}+=7,5$. Ця величина показує максимально можливу кількість хворих пацієнтів, яку можна очікувати після закінчення перших двох місяців з моменту операції.

\section{Таблиця 3}

Розподіл хворих відповідно до виникненням перших ознак IE ПКС у післяопераційному періоді (перші два місяиі)

\begin{tabular}{lccccccccc} 
Кількість & \multicolumn{8}{c}{ Тижні після операції } \\
\cline { 2 - 9 } хворих & $\mathbf{1}$ & $\mathbf{2}$ & $\mathbf{3}$ & $\mathbf{4}$ & $\mathbf{5}$ & $\mathbf{6}$ & $\mathbf{7}$ & $\mathbf{8}$ & Разом \\
\hline $\mathrm{n}$ & 5 & 13 & 16 & 25 & 19 & 12 & 11 & 8 & 109 \\
\hline$\%$ & 4,6 & 11,9 & 14,6 & 22,9 & 17,4 & 11,0 & 10,1 & 7,3 & 100,0
\end{tabular}

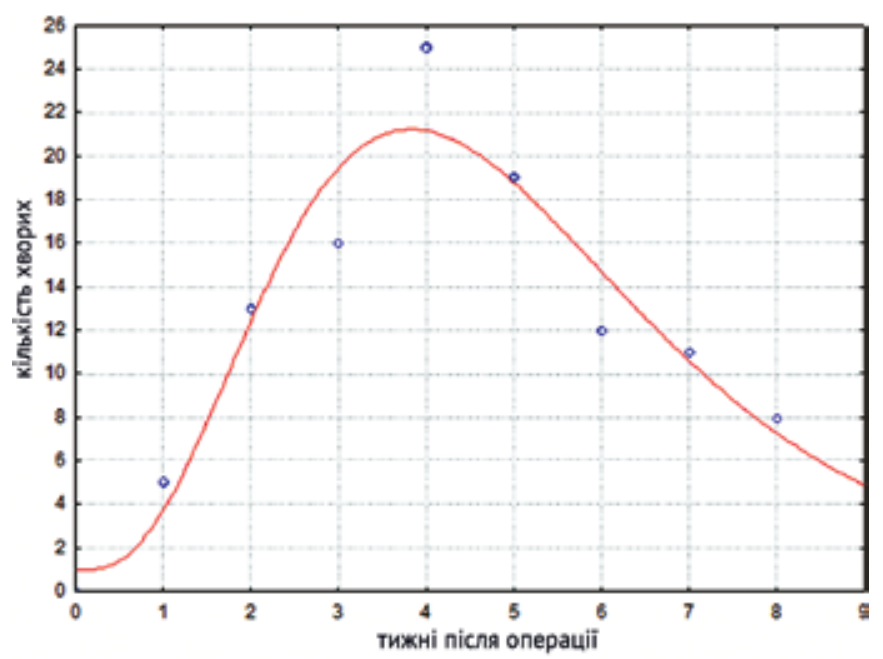

Рис. 1. Динаміка зміни кількості хворих відповідно до появи перших ознак IЕ ПКС у післяопераційному періоді (перші 2 місяиі)

З огляду на загальну кількістьпацієнтів, шо припадає на цей період $(\mathrm{n}=109)$ можна вважати, що ймовірність виникнення захворювання після двох місяців з моменту операції становить 7,5/109×100\% $\approx 7 \%$.

Аналіз розподілу хворих за моментом виникнення захворювання протягом 12 місяців після операції свідчить про те, що найбільша кількість припадає на термін у перші два місяці (табл. 5).

Найбільш адекватною формою математичного запису динаміки цього процесу також є функція (рис. 2).

Значення параметрів для цього випадку наведені в табл. 6. Як і раніше, найбільший інтерес становить величина $\mathrm{d}+$, яка в даному випадку дорівнює 7,5. 3 огляду на кількість пацієнтів, які захворіли в перший рік після операції (n=193), ймовірність розвитку захворювання після закінчення першого року з моменту хірургічного втручання становить $7,5 / 193 \times 100 \% \approx 4,0 \%$.

Таким чином, після першого року після операції ризик виникнення IE ПКС зменшується вдвічі порівняно із завершенням перших двох місяців післяопераційного періоду.

Таким чином, залежно від виникнення перших симптомів IЕ група хворих була підрозділена на ранні

\section{Таблиця 4}

\section{Значення параметрів моделі}

\begin{tabular}{llllll} 
& $\begin{array}{l}\text { Середні } \\
\text { значення }\end{array}$ & $\begin{array}{l}\text { Середньоквадра- } \\
\text { тичне відхилення }\end{array}$ & t-value & p-level & $\begin{array}{l}\text { Верхня } \\
\text { межа }\end{array}$ \\
\hline a & 6,444 & 3,661 & 1,760 & 0,139 & 15,854 \\
\hline b & 3,331 & 1,193 & 2,792 & 0,038 & 6,399 \\
\hline c & 0,869 & 0,299 & 2,912 & 0,033 & 1,637 \\
\hline d & 0,991 & 2,535 & 0,391 & 0,712 & 7,507
\end{tabular}




\section{Таблиця 5}

Розподіл хворих відповідно до виникненням перших ознак IE ПКС у післяопераційному періоді (перші 12 місяців)

\begin{tabular}{|c|c|c|c|c|c|c|c|c|c|c|c|c|c|}
\hline \multirow{2}{*}{$\begin{array}{l}\text { Кількість } \\
\text { хворих }\end{array}$} & \multicolumn{12}{|c|}{ Місяці першого року після операції } & \multirow[b]{2}{*}{ Разом } \\
\hline & 1 & 2 & 3 & 4 & 5 & 6 & 7 & 8 & 9 & 10 & 11 & 12 & \\
\hline $\mathrm{n}$ & 67 & 42 & 25 & 13 & 11 & 9 & 7 & 5 & 6 & 3 & 3 & 2 & 193 \\
\hline
\end{tabular}

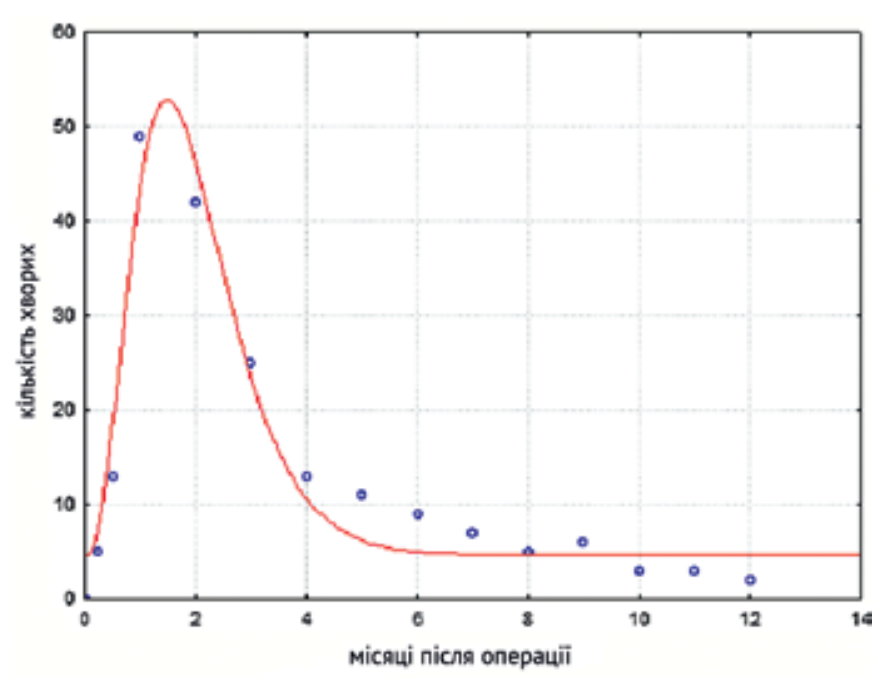

Рис. 2. Динаміка зміни кількості хворих відповідно до появи перших ознак IE ПКС у післяопераційному періоді (12 місяиів)

\section{Таблиця 6}

Значення параметрів моделі

\begin{tabular}{lccccc} 
& $\begin{array}{c}\text { Середні } \\
\text { значення }\end{array}$ & $\begin{array}{c}\text { Середньоквадра- } \\
\text { тичне відхилення }\end{array}$ & t-value & p-level & $\begin{array}{c}\text { Верхня } \\
\text { межа }\end{array}$ \\
\hline a & 288,9271 & 111,0337 & 2,6022 & 0,0246 & 533,3106 \\
\hline b & 2,9718 & 0,5643 & 5,2661 & 0,0003 & 4,2139 \\
\hline c & 1,9973 & 0,3712 & 5,3804 & 0,0002 & 2,8143 \\
\hline d & 4,5758 & 1,3324 & 3,4342 & 0,0056 & 7,5084
\end{tabular}

(менше 2 місяців після операції) і пізні (більше 2 місяців після операції) форми захворювання, які включили $109(39,5 \%)$ і 167 (60,5\%) випадків відповідно. Відповідно до анатомічних позицій ШКС були систематизовані випадки ранніх і пізніх форм захворювання. Спостерігається достовірне переважання пізніх форм захворювання в кожній підгрупі клапанів лівих відділів серця (табл. 7).

Розподіл випадків виникнення IE ПКС у післяопераційному періоді має нерівномірній характер. Найбільша кількість випадків припадає на четвертий тиждень після імплантації ШКС. До кінця другого місяця
Таблиця 7

Розподіл пацієнтів відповідно до анатомічних позицій імплантованих ШКС і термінів виникнення симптомів IE ПKC

\begin{tabular}{lcccccc}
\multirow{2}{*}{$\begin{array}{l}\text { Анатомічна } \\
\text { позиція }\end{array}$} & \multicolumn{2}{c}{ Ранній IE } & \multicolumn{2}{c}{ Пізній IE } & \multicolumn{2}{c}{ Разом } \\
\cline { 2 - 7 } & $\mathbf{n}$ & $\mathbf{\%}$ & $\mathbf{n}$ & $\mathbf{\%}$ & $\mathbf{n}$ & $\mathbf{\%}$ \\
\hline Аортальна & 54 & 19,6 & 75 & $27,2^{* * *}$ & 129 & 46,7 \\
\hline Мітральна & 41 & 14,9 & 67 & $24,3^{* * *}$ & 108 & 39,1 \\
\hline $\begin{array}{l}\text { Мітрально- } \\
\text { аортальна }\end{array}$ & 12 & 4,3 & 20 & $7,2^{* *}$ & 32 & 11,6 \\
\hline Тристулкова & 2 & 0,7 & 5 & $1,8^{*}$ & 7 & 2,5 \\
\hline Разом & 109 & 39,5 & 167 & 60,5 & 276 & 100,0
\end{tabular}

Примітка. Рівні значущості при порівнянні частоти ранніх і пізніх форм IЕ відповідно до позицій імплантації ПКС: * $(\mathrm{p} \approx 0,1)$; $* *(\mathrm{p}<0,05) ; * * *(\mathrm{p}<0,01)$

ризик виникнення IЕ ПКС становить 7\%, а до кінця першого року після операції він зменшується вдвічі, дорівнюючи $4 \%$.

\section{Висновки}

1. Ранні та пізні форми IЕ ПКС виявлені в $109(39,5 \%)$ та 167 (60,5\%) випадках відповідно.

2. Фаза найбільшого ризику розвитку IE в післяопераційному періоді - перші два місяці після хірургічного втручання.

3. До кінця другого місяця ризик виникнення IE ПКС становив 7\%, а до кінця першого року після операції він зменшився майже вдвічі, складаючи $4 \%$.

4. Спостерігається достовірне переважання пізніх форм серед груп IЕ ПКС лівих відділів серця.

\section{Лiтература}

1. Comparison between early and late prosthetic valve endocarditis: clinical characteristics and outcomes / Nonaka M., Kusuhara T., An K. et al. // J Heart Valve Dis. - 2013 Jul. - Vol. 22 (4). - P. 567-74.

2. Twenty-year single-center experience with the Medtronic open pivot mechanical heart valve / Van Nooten G., Bovй T., Van Belleghem Y. et al. // Ann Thorac Surg. 2014. - Vol. 97. - P. 1306-1313. doi: 10.1016/j. athoracsur.2013.11.035. [PubMed] [Cross Ref]

3. Recurrent prosthetic valve endocarditis with aorticventricular disruption: a surgical challenge / Ramlawi B., 
White L. E., Santora R. J. et al. // J Heart Valve Dis. 2013. - Vol. 22. - P. 126-133. [PubMed]

4. Surgical treatment of prosthetic valve endocarditis / Lytle B. W., Priest B. P., Taylor P. C. et al. // J Thorac Cardiovasc Surg. - 1996. - Vol. 111. - P. 198-207. doi: 10.1016/S0022-5223(96)70417-8. [PubMed] [Cross Ref]

5. Outcome after surgery for prosthetic valve endocarditis and the impact of preoperative treatment / Grubitzsch H., Schaefer A., Melzer C. et al. // J Thorac Cardiovasc Surg. 2014. [PubMed]

6. In-hospital and 1-year mortality in patients undergoing early surgery for prosthetic valve endocarditis / Lalani T., Chu V. H., Park L. P. et al. // JAMA Intern Med. -2013. - Vol. 173. - P. 1495-1504. doi: 10.1001/ jamainternmed.2013.8203. [PubMed] [Cross Ref]
7. Comparison between early and late prosthetic valve endocarditis: clinical characteristics and outcomes / Nonaka M., Kusuhara T., An K. et al. // J Heart Valve Dis. - 2013. - Vol. 22. - P. 567-574. [PubMed]

8. The relationship between the initiation of antimicrobial therapy and the incidence of stroke in infective endocarditis: An analysis from the ICE Prospective Cohort Study (ICE-PCS) / Dickerman Stuart A. et al. // American Heart Journal. - Vol. 154, Issue 6. P. 1086-1094.

9. Misawa Y. Valve-related complications after mechanical heart valve implantation // Surgery Today. - 2015. - Vol. 45 (10). - P. 1205-1209. doi:10.1007/s00595-014-1104-0.

\title{
Terms of early and late prosthetic valve endocarditis
}

\author{
Krikunov A. A., Koltunova A. B., Spysarenko S. P., Malysheva T. A. \\ National M. M. Amosov Institute of Cardiovascular Surgery National Academy of Medical Sciences of Ukraine (Kyiv)
}

Prosthetic valve endocarditis (PVE) is one of the severe complications of the postoperative period from the side of implanted artificial heart valves. Early PVE is associated with mortality rate over 75\%. Objectives: to investigate the terms early and lateprosthetic valve endocarditis. Materials and methods. The basis of the study was the clinical data of 276 patients withPVE, who underwent examination and treatment at the SE «AmosovNational Institute of Cardiovascular Surgery AMS

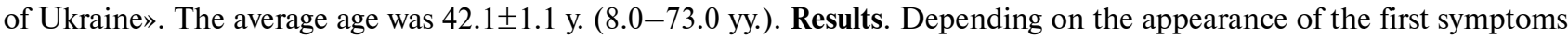
ofPVE, the group of patients was subdivided into early (less than 2 months after surgery) and late (more than 2 months after surgery)PVE, which included 109 (39.5\%) and 167 (60.5\%) cases respectively. By the end of the second month, the risk of PVE was 6\%, and by the end of the first year after surgery, it was almost halved by $4 \%$. Conclusions. Distribution of occurrence of PVE in the postoperative period was unequal. The greatest number of cases occur on the fourth week after implantation of an artificial heart valve.

Key words: prosthetic valve endocarditis, early prosthetic valve endocarditis, late prosthetic valve endocarditis.

\section{Сроки возникновения ранних и поздних форм инфекционного эндокардита протезированного клапана сердца}

\author{
Крикунов А. А., Колтунова А. Б., Списаренко С. П., Малышева Т. А. \\ ГУ «Национальный институт сердечно-сосудистой хирургии имени Н. М. Амосова НАМН» (Киев)
}

\begin{abstract}
Инфекционный эндокардит протезированного клапана сердца (ИЭ ПКС) является одним из тяжелых осложнений послеоперационного периода со стороны имплантированных искусственных клапанов сердца. Особой тяжестью отличаются ранние формы ИЭ ПКС, летальность при которых достигает 75\%. Цель - исследовать сроки возникновения и клинические проявления ранних и поздних форм ИЭ ПКС. Материалы и методы. Основу исследования составили клинические данные 276 больных ИЭ ПКС, прошедших обследование и лечение в ГУ «Национальный институт сердечно-сосудистой хирургии имени Н. М. Амосова НАМН» 01.01 .1997 по 31.12 .2017

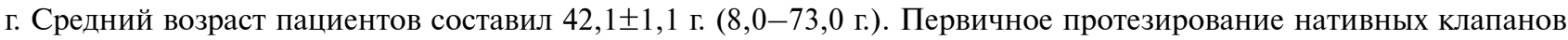
сердца было выполнено в НИССХ у 276 больных (100\% случаев). Результаты. В зависимости от возникновения первых симптомов ИЭ группа больных с ПКС была подразделена на подгруппы ранней (менее 2 месяцев после операции) и поздней (более 2 месяцев после операции) формы заболевания - 109 (39,5\%) и 167 (60,5\%) случаев соответственно. К концу второго месяца риск возникновения ИЭ ПКС составил 7\%, а к концу первого года после операции он уменьшился почти вдвое - 4\%. Выводы. Распределение случаев возникновения ИЭ ПКС в послеоперационном периоде имеет неравномерный характер. Наибольшее количество случаев приходится на четвертую неделю после имплантации искусственного клапана сердца.
\end{abstract}

Ключевые слова: инфекционный эндокардит протезированного клапана сердиа, ранние формы, поздние формы. 